\title{
Memaksimalkan Potensi Literasi Bahasa dan Budaya Jawa di Kecamatan Galur, Kabupaten Kulon Progo
}

\section{Daru Winarti}

Program Studi Jawa, Departemen Bahasa dan Sastra, Fakultas Ilmu Budaya, Universitas Gadjah Mada

Pos-el: daru.w@ugm.ac.id

Tim Pengabdian kepada Masyarakat:

Daru Winarti, R. Bima Slamet Raharja, Anung Tedjowirawan, Sumarsih, Marsono, Arsanti Wulandari, Hendrokumoro, Sulistyowati, Soeharto Mangkusoedarmo, Sri Ratna Saktimulya, Akhmad Nugroho, Rudi Wiratama, Wisma Nugraha Ch, Djarot Heru Santosa, Wiwien Widyawati Rahayu

\begin{abstract}
Galur Subdistrict is an area that has abundant art and tradition potential and is in great demand by its people. Unfortunately, the art performances and traditions that are carried out only aim merely to continue what have been done through generations. On the other hand, the influx of modern arts has become a threat to preserving traditional culture, especially among young people who are supposed to be the guardians of the traditions. This encourages Javanese Literature Study Program to carry out a community service program consisting of a series of training program as the Study Program's concern and real action for cultural preservation.

The training program is carried out through mentoring in motivating, counseling, education, discussion, and consultation. By using such mentoring techniques, it is expected that the result of the program will be optimum, namely raising public awareness to increase language literacy, knowledge of literature, and the knowledge of the art performances they have. In turn, they will be able to manage the performances as a professional art performance organizer in the region.

The outcomes of the community service program comprise the increasing ability of participants in reading and writing simple texts using Javanese alphabet, participants' ability to compose macapat songs and sing them, the participants' ability to write Javanese poems with the rinengga language, the participants' ability create a series of dances and nursery rhymes to be performed, and the participants' ability to become masters of ceremonies. In addition, three versions of Folklore about K.R.T Kertinegara are also collected.
\end{abstract}

Keywords: language literacy, Javanese culture, Galur Subdistrict

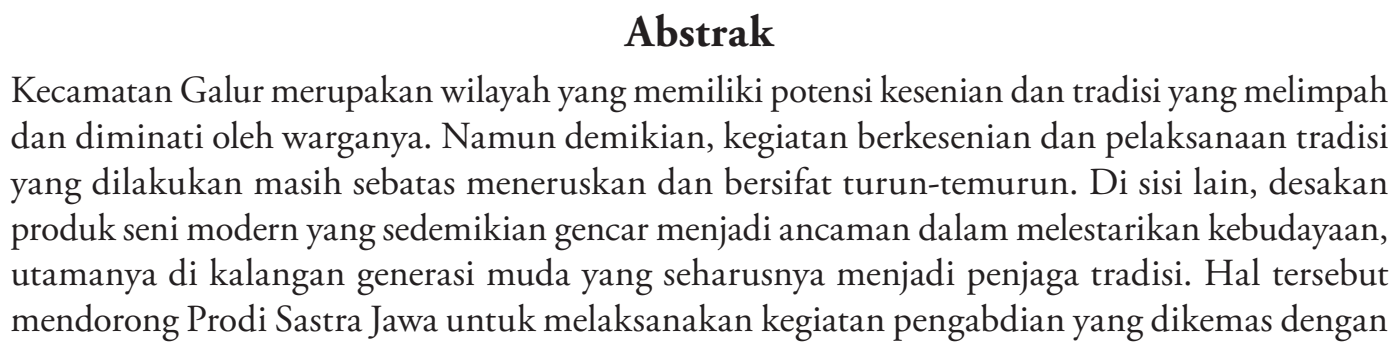


metode pelatihan sebagai bentuk kepedulian Prodi Sastra Jawa dalam rangka pelestarian budaya. Metode pelatihan dilakukan dengan cara pendampingan dalam bentuk pemberian motivasi, penyuluhan, edukasi, diskusi, dan konsultasi. Dengan menggunakan metode pendampingan tersebut diharapkan dapat membuahkan hasil yang optimal, yaitu adanya kesadaran masyarakat untuk meningkatkan berbagai pengetahuan kebahasaan, kesastraan, dan seni pertunjukan yang dimilikinya, hingga selanjutnya dapat mengelolanya menjadi kegiatan kelompok yang terorganisasi di wilayahnya.

Adapun hasil dari kegiatan pengabdian di Kecamatan Galur ini meliputi meningkatnya kemampuan peserta dalam hal membaca dan menulis teks sederhana menggunakan huruf Jawa. Peserta dapat menggubah tembang macapat dan sekaligus melantunkannya, membuat geguritan dengan bahasa rinengga, membuat rangkaian tari dan tembang dolanan untuk ditampilkan, dan mampu berlaku sebagai pranatacara. Dalam pengabdian ini juga berhasil dikumpulkan tiga versi cerita rakyat tentang K.R.T Kertinegara.

Kata kunci: memaksimalkan, literasi bahasa, budaya Jawa, Kecamatan Galur

\section{Pendahuluan}

Kecamatan Galur merupakan salah satu dari dua belas kecamatan yang tercakup dalam wilayah Kabupaten Kulon Progo dan terdiri atas tujuh desa, yakni Brosot, Kranggan, Banaran, Nomporejo, Karangsewu, Pandowan, dan Tirtorahayu. Secara geografis, Kecamatan Galur berbatasan dengan Kecamatan Lendah di sebelah utara, Samudera Indonesia di selatan, Kecamatan Panjatan di sebelah barat, dan Kabupaten Bantul di sebelah timur. Dengan demikian, dilihat dari kenampakan alamnya, Kecamatan Galur memiliki karakteristik masyarakat berkebudayaan agraris dan maritim sekaligus.

Berdasarkan catatan sejarah, keberadaan Kecamatan Galur tidak terlepas dari sejarah politik dan kebudayaan yang melibatkan kerajaan-kerajaan Swapraja pecahan Mataram, terutama Kasultanan Yogyakarta dan Kadipaten Pakualaman. Sebagai bagian dari Kadipaten Pakualaman, Kecamatan Galur pernah tercatat sebagai bagian dari Kabupaten Adikarta yang selanjutnya disebut dengan nama Kabupaten Karang Kemuning, dengan Brosot sebagai ibukotanya. Peristiwa ini terjadi pada masa pemerintahan Sri Paduka Paku Alam V sekitar 1877 Masehi. Kaitan antara masyarakat Galur dan Kadipaten Pakualaman serta pendahulunya juga dapat dicermati melalui cerita rakyat setempat yang menyatakan bahwa masyarakat di daerah tersebut adalah keturunan dari pasukan Pranaraga (Ponorogo) yang bertugas melindungi keluarga kerajaan Mataram dari kejaran Trunojoyo. Atas keberhasilan mereka, kemudian berdirilah daerah yang dikenal dengan nama "Kulon Praga", selain berasal dari keadaan geografisnya yang terletak di barat sungai Progo, juga dipercaya memiliki kaitan erat dengan pasukan dari Ponorogo yang bertugas membantu kerajaan Mataram, dengan kata "Pranaraga" yang diubah menjadi "Praga" setelah melalui proses distorsi turun-temurun. Wilayah Kecamatan Galur di masa lampau juga identik dengan keberadaan Pabrik Gula "Sewoe Galoer" yang menjadi satu-satunya pabrik pengolahan gula milik Kadipaten Pakualaman, yang menjadi sumber kemakmuran masyarakat pada zamannya dan bahkan sempat menjadikan wilayah Galur sebagai daerah yang penting bagi perekonomian Kabupaten Adikarta dan Kadipaten Pakualaman. Akhirnya, pabrik tersebut ditutup setelah situasi politik semakin tak menentu dan jalur pengangkutan tebu ke ibukota Yogyakarta hancur pada masa pendudukan Jepang (1942-1945). 
Dalam bidang seni dan kebudayaan Jawa, wilayah Kecamatan Galur memiliki banyak potensi yang dapat digali, direvitalisasi, dan diaktualisasikan dengan optimal sehingga masyarakat dapat mengambil manfaatnya, baik manfaat ekonomis, edukatif, maupun sosial. Produk seni budaya Jawa yang berkembang di wilayah Galur, Kulon Progo di antaranya adalah Reog Wayang, Karawitan, Panembrama, Kethoprak, Macapatan, dan Pranatacara. Selain itu, adat dan ritual masyarakat setempat yang terkait dengan kebudayaan Jawa juga masih dapat ditemukan dalam berbagai tahap daur hidup. Hingga saat ini, produk seni budaya Jawa yang berkembang di wilayah Galur, Kabupaten Kulon Progo masih sebatas nguri-uri atau nalurekke, yaitu sekadar meneruskan apa yang telah diwariskan oleh generasi pendahulu. Sementara itu, di sisi lain produk seni budaya modern terus masuk dan digemari oleh masyarakat setempat, terutama yang berusia muda sehingga timbul kekhawatiran tentang proses kaderisasi dan regenerasi produk seni tradisi dan kebudayaan Jawa di Kecamatan Galur, Kabupaten Kulon Progo, yang akan menjadi titik tolak kegiatan pengabdian masyarakat Prodi Sastra Jawa, Departemen Bahasa dan Sastra, Fakultas Ilmu Budaya, Universitas Gadjah Mada, Yogyakarta.

\section{Pembahasan}

Kecamatan Galur memiliki potensi kesenian dan tradisi yang melimpah serta diminati oleh warganya. Kesenian yang berkembang utamanya berupa seni pertunjukan Reog Wayang, Macapatan, dan Pranatacara, yang semuanya itu masih sebatas meneruskan dan bersifat turun-temurun dari leluhur. Di sisi lain, masuknya produk seni modern menjadi ancaman dalam melestarikan kebudayaan, utamanya di kalangan generasi muda. Hal tersebut mendorong Prodi Sastra Jawa untuk melaksanakan kegiatan pengabdian yang dikemas dengan metode pelatihan sebagai bentuk kepedulian Prodi Sastra Jawa dalam rangka pelestarian budaya. Pelaksanaan kegiatan pengabdian kepada masyarakat diawali dengan koordinasi dengan pejabat setempat terkait peserta dan tempat pelatihan. Setelah menentukan peserta yang sesuai dengan tujuan pengabdian, dilanjutkan dengan pelaksanaan berupa lima bidang kegiatan pelatihan, yakni membaca dan menulis aksara Jawa, tari dan tembang dolanan, macapat, pranatacara, serta geguritan. Melalui pelatihan tersebut, peserta diharapkan dapat memahami materi yang diperoleh dan mengimplementasikannya di instansi dan/atau lingkungan masing-masing.

Tabel 1.

\begin{tabular}{|c|c|c|c|c|}
\hline \multirow{2}{*}{ No. } & \multirow{2}{*}{ Kegiatan } & \multicolumn{2}{|c|}{ Jumlah } & \multirow{2}{*}{ Keterangan } \\
\hline & & Peserta & Pendamping & \\
\hline 1 & Membaca dan Menulis Aksara Jawa & 20 & 2 & \multirow{6}{*}{$\begin{array}{l}\text { Petugas } \\
\text { Kecamatan: } \\
5 \text { orang }\end{array}$} \\
\hline 2 & Pelatihan Macapat & 17 & 1 & \\
\hline 3 & Menulis dan Membaca Geguritan & 20 & 1 & \\
\hline 4 & Tari dan Tembang dolanan & 19 & 2 & \\
\hline 5 & Pelatihan Bahasa Jawa dan Pranatacara & 20 & 5 & \\
\hline 6 & Pengumpulan Data dan Cerita Rakyat & 4 & 12 & \\
\hline \multicolumn{2}{|r|}{ Jumlah } & 100 & 23 & 6 \\
\hline & Total & \multicolumn{3}{|c|}{129} \\
\hline
\end{tabular}


Kegiatan Pengabdian kepada Masyarakat dilakukan oleh Program Studi Sastra Jawa FIB UGM pada 7 dan 8 Juli 2018 diikuti oleh 129 orang, terdiri atas 100 peserta dari Kecamatan Galur dengan rincian: 23 anggota tim pendamping dari Prodi Sastra Jawa FIB UGM, 1 orang sie dokumentasi, dan 5 orang petugas kecamatan. Peserta dikelompokkan menjadi beberapa bidang pelatihan dengan didampingi oleh tim dari Prodi Sastra Jawa FIB UGM. Pembagian peserta disajikan dalam Tabel 1.

Berbagai kegiatan tersebut dipersiapkan sedetail mungkin supaya dapat dilaksanakan dengan sebaik-baiknya. Namun demikian, dalam pelaksanaannya tetap terdapat kendala. Hal tersebut akan diuraikan berikut ini.

\section{Pelatihan Membaca dan Menulis Aksara Jawa}

Persiapan pelatihan membaca dan menulis aksara Jawa meliputi materi pelatihan dan metode pelatihan. Materi pelatihan berupa: 20 aksara Jawa; 3 macam sandhangan; swara, panyigeg wanda, dan wijanjana; pasangan aksara Jawa; aksara rekan, murda, dan swara; angka Jawa, pada, dan lainnya. Metode pelatihan yang digunakan yaitu mahasiswa membagikan bahan ajar, dosen menjelaskan materi membaca dan menulis aksara Jawa, sedangkan peserta mempraktikkan materi yang diberikan. Dosen dan mahasiswa mendampingi peserta pelatihan berlatih menulis aksara Jawa yang topiknya disesuaikan dengan keinginan peserta.

Adapun hasil dari pelatihan di antaranya adalah peserta mampu membaca teks sederhana beraksara Jawa. Peserta juga mampu menulis dengan aksara Jawa. Hasil tulisan peserta ditampilkan di depan peserta pelatihan lain saat acara penutupan.

Beberapa kendala yang dihadapi dalam pelatihan penulisan aksara Jawa di antaranya adalah ruang pelatihan yang sempit sehingga suasana pelatihan tidak terlalu nyaman. Selain itu, beberapa peserta kurang memperhatikan pemateri, diperlukan pula bahan untuk belajar mandiri, dan waktu pelatihan yang terlalu singkat.

\section{Pelatiban Macapat}

Sama halnya dengan persiapan pelatihan membaca dan menulis aksara Jawa, pelatihan macapat juga dipersiapkan dengan matang dalam hal materi dan metode. Materi macapat yang dipersiapkan meliputi batasan pengertian dan kaidah tembang macapat, sandiasma, laras gamelan dan tembang, serta nama dan karakter masing-masing tembang macapat. Metode pelatihan yang dipersiapkan yaitu mahasiswa membagikan bahan ajar, dosen menjelaskan materi tembang macapat, peserta diberi kesempatan berdiskusi, dosen mengajarkan cara membaca titi laras tembang macapat, peserta menggubah lirik tembang macapat, kemudian peserta menyanyikan hasil karya masing-masing.

Dari hasil persiapan tersebut dapat diperoleh hasil seperti yang diharapkan, yaitu peserta memahami teori yang disampaikan, menggubah tembang macapat dengan sandiasma, dan mempertunjukkan kemampuannya dengan menyanyikan tembang macapat dandanggula dan kinanthi.

Pelatihan macapat dengan hasil tersebut kiranya akan lebih maksimal jika kendala berikut dapat diatasi, di antaranya adalah tidak ada gender untuk membantu peserta mengetahui tinggi rendahnya nada, waktu pelatihan terlalu singkat, para peserta masih malu dalam mengekspresikan tembang gubahannya. 


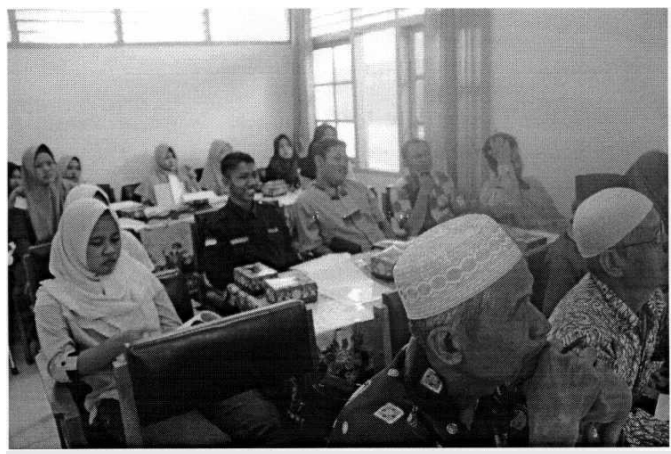

Gambar 1. Pelatihan Macapat

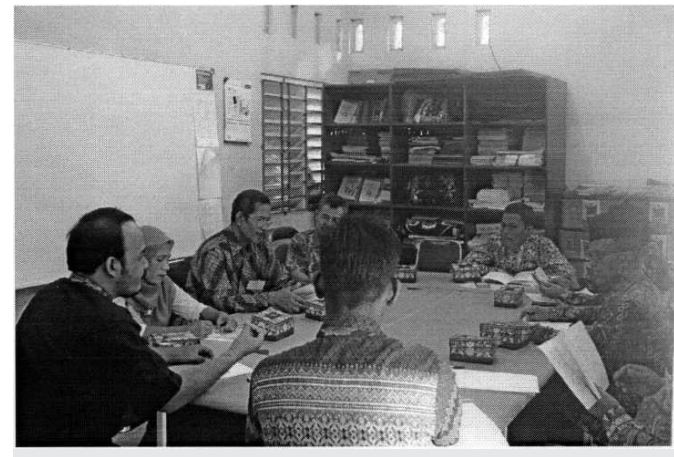

Gambar 2. Pelatihan Macapat

\section{Pelatiban Menulis dan Membaca Geguritan}

Pelatihan menulis dan membaca geguritan dipersiapkan seperti halnya menulis dan membaca aksara Jawa serta macapatan, yaitu persiapan materi pelatihan dan metode pelatihan. Materi pelatihan meliputi cara menulis geguritan dan cara membaca geguritan yang baik dan benar. Adapun metode yang digunakan adalah mahasiswa membagikan bahan ajar, dosen menjelaskan materi pelatihan, peserta diberi kesempatan bertanya dan berdiskusi, peserta membuat geguritan, geguritan peserta dievaluasi oleh dosen terkait penulisan dan bahasanya, dan peserta menampilkan geguritan yang sudah dibuat.

Pelatihan geguritan dengan persiapan dan metode tersebut menghasilkan peserta yang mampu membuat geguritan dengan bahasa rinengga dan mampu menampilkan hasil karyanya dengan baik dan benar.

Walaupun sudah menghasilkan peserta yang demikian, masih ada beberapa kendala pelaksanaan pelatihan geguritan, di antaranya adalah beberapa peserta masih menuliskan kosa kata dengan ejaan yang salah, masih malu dalam mengekspresikan hasil karyanya di depan peserta lain, dan waktu pelatihan yang terlalu singkat.

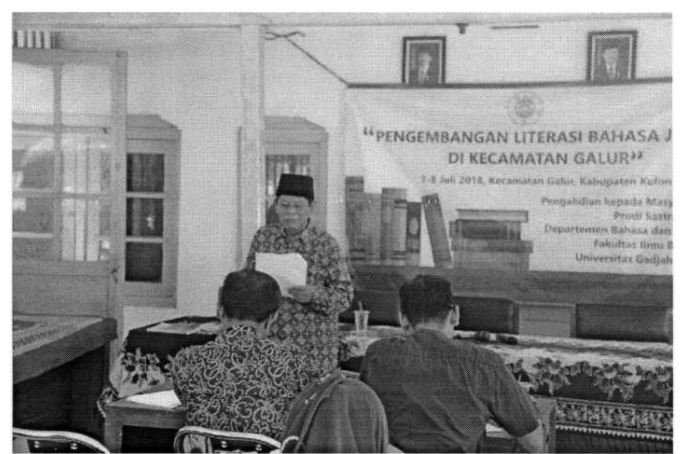

Gambar 3. Pelatihan Menulis dan Membaca Geguritan

\section{Pelatiban Tari dan Tembang Dolanan}

Kelompok pelatihan tari dan tembang dolanan merupakan kelompok yang kelasnya cukup meriah karena peserta harus bernyanyi sekaligus melakukan gerakan sesuai lirik lagu. Persiapan pelatihan pada kelompok ini yaitu materi pelatihan yang meliputi teori tentang aspek perkembangan yang distimulasi pada tari dan tembang dolanan. Materi tembang dolanan yang dipersiapkan yaitu teks tembang Baris Rampak, Kacang Goreng, Lepetan, Lindri, Sepuran, dan pelatih, baik untuk tembang dolanan maupun tarian yang terdiri atas dosen dan mahasiswa prodi Sastra Jawa. Adapun metode pelatihan yang digunakan yaitu mahasiswa membagikan bahan ajar, dosen menjelaskan materi pelatihan, dosen dan mahasiswa memberi contoh tari dan tembang dolanan, peserta 
diberi kesempatan untuk berlatih, kemudian peserta mempraktikkan materi yang diajarkan.

Hasil pelatihan dari kelompok ini adalah peserta dapat memahami aspek perkembangan anak yang distimulasi dengan tari dan tembang dolanan, peserta mengenal tari dan tembang dolanan yang belum pernah diketahui, mempraktikkan materi dengan baik, serta membuat rangkaian tari dan tembang dolanan untuk ditampilkan saat acara penutupan.

Beberapa kendala kendala yang dihadapi pada saat pelatihan tari dan tembang dolanan adalah ruang pelatihan kurang luas, waktu terlalu singkat, peserta masih malu pada saat menampilkan tari dan tembang dolanan.

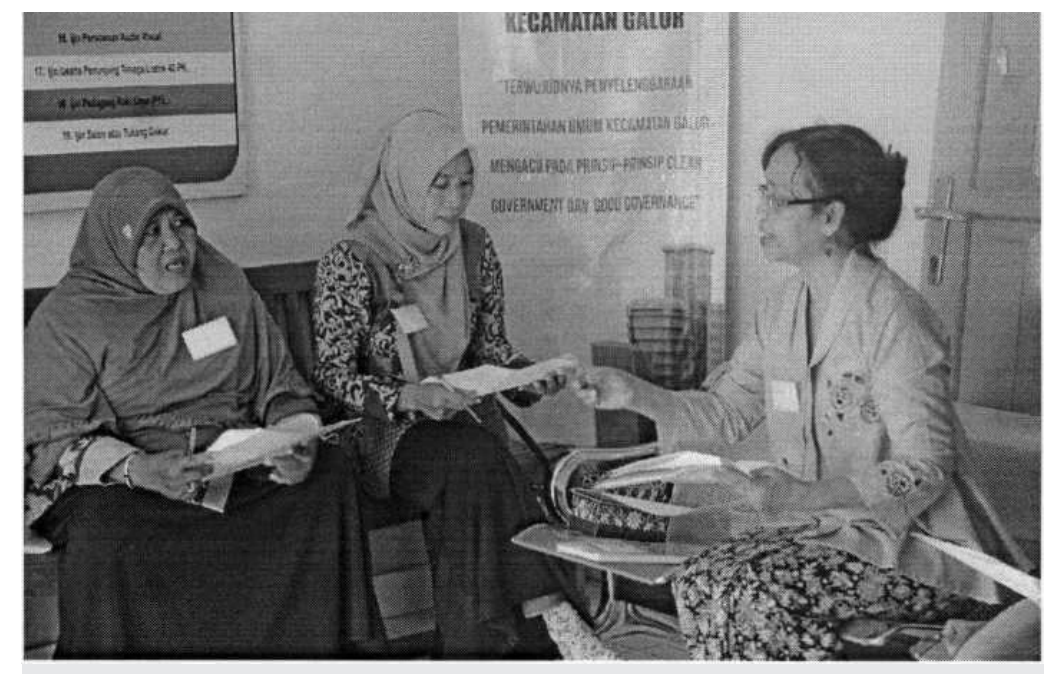

Gambar 4. Pelatihan Tari dan Tembang Dolanan

\section{Pelatihan Pranatacara}

Pranatacara atau sering dikenal dengan istilah MC termasuk pelatihan yang cukup diminati, baik peserta yang berusia tua maupun muda, mengingat semakin banyaknya acara atau upacara yang memerlukan kemampuan seorang MC berbahasa Jawa. Untuk memudahkan pelatihan maka dipersiapkan materi pelatihan dan metode pelatihan yang digunakan. Adapun materi pelatihan meliputi pengenalan kedudukan dan fungsi

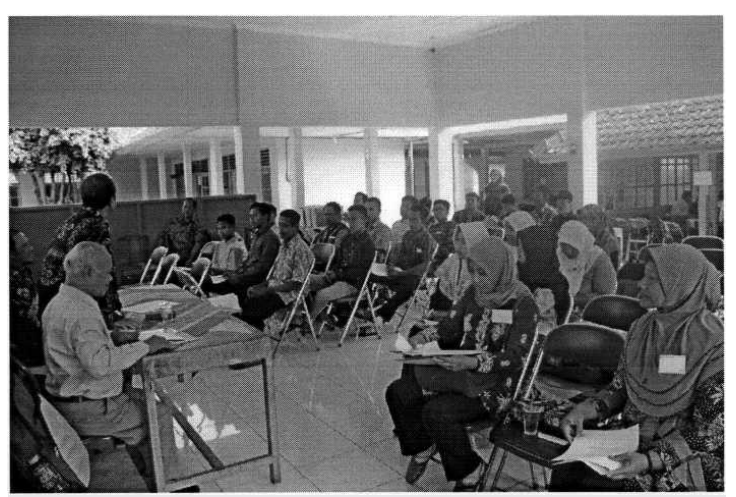

Gambar 5. Pelatihan Pranatacara bahasa Jawa, bahasa Jawa yang baik dan benar, pengenalan tingkat tutur bahasa Jawa, materi tuntunan untuk pranatacara. Sementara itu, metode pelatihan yang digunakan adalah mahasiswa membagikan 
bahan ajar, dosen menjelaskan materi pelatihan, peserta diberi kesempatan bertanya dan berdiskusi, peserta mempraktikkan materi pelatihan, kemudian peserta dievaluasi dan diberi masukan oleh dosen.

Hasil pelatihan yang diperoleh dengan materi dan metode di atas adalah peserta mampu memahami materi pelatihan, membedakan kosa kata yang benar dan salah, mempraktikkan materi pelatihan, dan salah satu peserta mampu berlaku sebagai pranatacara pada acara penutupan. Beberapa kendala pelatihan yang dirasakan pada pelatihan pranatacara adalah waktu pelatihan terlalu singkat dan peserta sering kali menggunakan kata yang tidak dipahami artinya (makempal, kita) karena kebiasaan di dalam masyarakatnya.

\section{Pendokumentasian Cerita Rakyat}

Kegiatan pendokumentasian dilaksanakan pada hari yang terpisah karena membutuhkan waktu lebih lama dalam mencari informan dan juga memerlukan situasi yang lebih santai supaya wawancara berjalan dengan menyenangkan serta memperoleh informasi yang maksimal. Wawancara dilakukan oleh mahasiswa yang langkah-langkah pelaksanaan dan metode pendokumentasiannya dimonitori oleh dosen. Adapun metode pendokumentasiannya meliputi pengarahan oleh dosen, yang meliputi cara mencari data awal dari buku dan internet, menyiapkan pertanyaan dan cara menanyakannya, menentukan nara sumber, yaitu Bapak Abdul Muthalib, Bapak Hadi Pranata, Bapak Panggiha, dan pelaksanaan oleh mahasiswa yang menyebar ke beberapa tempat. Hasil pendokumentasian yang diperoleh berupa cerita rakyat tentang K.R.T Kertinegara dalam tiga versi, namun tidak ada bukti autentik tentang silsilah K.R.T Kertinegara.

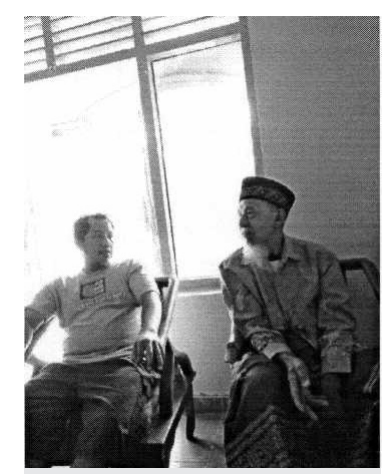

Gambar 6.

Pendokumentasian Cerita Rakyat

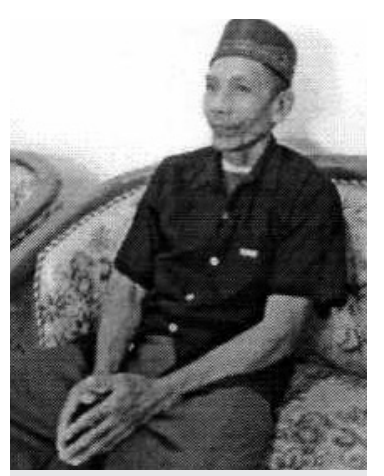

Gambar 7.

Bapak Panggiha, Narasumber Cerita Rakyat

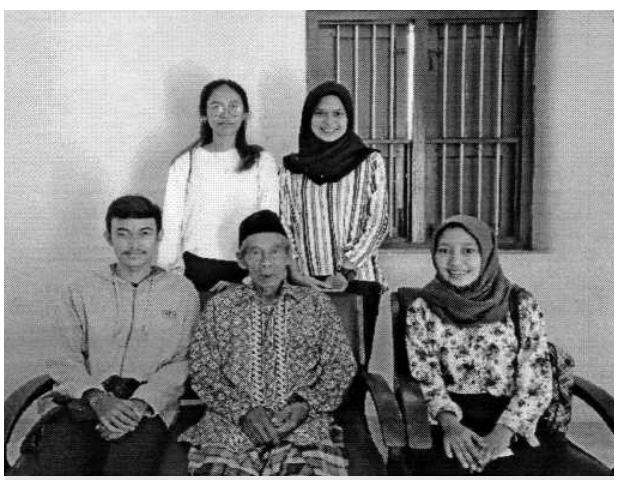

Gambar 8. Bapak Samingun dan Bapak Hadi Pranata, Narasumber Cerita Rakyat 


\section{Rencana Tindak Lanjut}

Berbagai pelatihan yang telah dilakukan ini diharapkan akan dapat ditindaklanjuti dengan berbagai aktivitas lainnya, yang di antaranya akan diuraikan sebagai berikut.

- Hasil pelatihan membaca dan menulis aksara Jawa akan menciptakan tenaga yang mumpuni dalam hal aksara Jawa sehingga dapat menularkannya kepada orang lain atau generasi selanjutnya. Dengan demikian, aksara Jawa tetap dapat dipertahankan dan terus digunakan untuk berbagai keperluan, seperti penamaan jalan, gedunggedung, dan hotel. Hasil pelatihan tembang macapat dan geguritan diharapkan dapat ditindaklanjuti dengan seringnya tembang macapat atau geguritan ditampilkan dan memiliki kader andal yang dapat membentuk kelompok macapat. Hasil pelatihan tari dan tembang dolanan diharapkan menjadikan peserta mampu mempraktikkan tari dan tembang dolanan di depan umum dan juga menerapkannya materi di sekolah masing-masing karena sebagian besar peserta pelatihan adalah guru PAUD.

- Hasil pelatihan bahasa Jawa dan pranatacara dapat ditindaklanjuti dengan peserta mampu bertindak sebagai pranatacara pada acara-acara di desa masing-masing dan juga dapat menjadi pelatih yang andal di desanya masing-masing. Hasil kegiatan pengumpulan data dan cerita rakyat akan diolah dan dijadikan buku sebagai salah satu wujud pelestarian budaya.

\section{Penutup}

Kegiatan Pengabdian kepada Masyarakat yang dilaksanakan di Kecamatan Galur mendapat apresiasi yang baik dari warga sekitar, yang dibuktikan dengan antusiasme masyarakat yang hadir pada acara tersebut. Peserta dari berbagai kalangan usia hadir mengikuti kegiatan pelatihan dan dapat merasakan manfaat dari kegiatan ini sebagaimana yang mereka tuliskan pada lembar kesan dan pesan. Melalui kegiatan ini, peserta mampu mempraktikkan materi yang diberikan oleh tim pengabdian sesuai kelas masing-masing. Demikian laporan kegiatan Pengabdian kepada Masyarakat yang dilakukan oleh Program Studi Sastra Jawa di Kecamatan Galur, Kabupaten Kulon Progo, Daerah Istimewa Yogyakarta.

\section{Daftar Pustaka}

Albiladiyah, S. Ilmi. tt. Pura Pakualaman Selayang Pandang. Jakarta: Departemen Pendidikan dan Kebudayaan.

Mumiatmo, Gatot dkk. 1989. Pola Penguasaan, Pemilikan dan Penggunaan Tanah secara Tradisional di Daerah Istimewa Yogyakarta. Jakarta: Departemen Pendidikan dan Kebudayaan).

"Sejarah Singkat Kabupaten Kulonprogo" dalam situs Badan Perpustakaan dan Arsip Daerah Istimewa Yogyakarta bpad.jogjaprov.go.id/article/news/view/sejarahsingakat- kabupaten-kulonprogo-1485 diakses pada 15 Juli 2018 pukul 8.25 WIB. 